\title{
Evaluation of different treatment protocols for combined injury-induced lung injury in rabbits
}

\author{
Xiao Bing Li, M.D. \\ Department of Burn and Plastic Surgery, Tianjin First Center Hospital, Tianjin-PR China
}

\begin{abstract}
BACKGROUND: This study aims to evaluate the effectiveness of different treatment regimens on combined injury-induced lung injury.

METHODS: Rabbits were subjected to non-lethal closed-chest bilateral lung contusion followed by a $30 \%$ total body surface area scald burn. The rabbits were randomly assigned to resuscitation groups that maintained a minimum mean arterial blood pressure of $70 \mathrm{mmHg}$ using one of the following three methods: normal saline plus polygeline injection in a ratio of $\mathrm{I}: \mathrm{I}$ (I:IG), normal saline plus polygeline injection in a ratio of $I: 2(\mathrm{I}: 2 \mathrm{G})$, and normal saline plus polygeline injection in a ratio of $\mathrm{I}: 3$ ( $\mathrm{I}: 3 \mathrm{G})$, After injury, lung injury was assessed using lung wet-to-dry (W/D) weight ratio, enzyme-linked immunosorbent assay, and real-time PCR.
\end{abstract}

RESULTS: In the I:3 fluid resuscitation group, rabbits exhibited significantly reduced lung W/D ratio, alveolar hemorrhage, myeloperoxidase activity, and IL-8 and TNF- $\alpha$ levels in the serum compared with the I:I or I:2 fluid resuscitation groups. The I:3 fluid resuscitation-treated rabbits also attenuated ultrastructural changes in the lung $24 \mathrm{~h}$ after the combined injury.

CONCLUSION: This study demonstrated the impact of fluid resuscitation on combined injury-induced lung injury. Further, $1: 3$ fluid resuscitation treatment at the early stage of lung injury after combined lung contusion and burn injury was found to be more effective.

Keywords: Acute lung injury; burn injury; fluid resuscitation; lung contusion.

\section{INTRODUCTION}

Combined lung contusion (LC) and burn injuries increases morbidity and mortality by promoting severe lung injury and hemodynamic shock. ${ }^{[1-3]}$ Burn injury alone, even in the absence of smoke inhalation, often causes damage to the lung tissue. ${ }^{[4]}$ In recent years, increasing evidence has suggested that neutrophils play an important role in the pathophysiology of burn-induced lung injury. ${ }^{[5,6]}$ LC is associated with acute respiratory failure, exhibiting as clinical acute lung injury (ALI) and acute respiratory distress syndrome (ARDS). ${ }^{[7,8]}$

Proper fluid resuscitation is critical for the survival of the

Address for correspondence: Xiao Bing Li, M.D.

Department of Burn and Plastic Surgery, Tianjin First Center

Hospital, Tianjin 300192, China

Tel: +862223626258 E-mail: fzhwyl98I@|63.com

Submitted: 04.05 .2015

Ulus Travma Acil Cerrahi Derg

Accepted: 20.10.2016

2017;23(5):362-367

doi: $10.5505 /$ tjtes.2017.21736

Copyright 2017

TJTES victim of a major burn injury. ${ }^{[9,10]}$ With adoption of weight and injury size-based formulas for resuscitation, multiple organ dysfunctions and inadequate resuscitation have become uncommon. However, LC is sensitive to fluid resuscitation after trauma. Such treatment can increase the lung water content and lead to desaturation. ${ }^{[1]}$ The decision to use colloid or crystalloid solutions for fluid resuscitation of critically ill patients remains controversial.

In the light of these findings, we hypothesized that fluid resuscitation can provide protection against combined LC and burn injury-induced pulmonary damage. We aimed to investigate whether and to what extent fluid resuscitation reduces this damage by determining the presence of oxidative tissue injury using biochemical and histological parameters.

\section{MATERIALS AND METHODS}

\section{Animals}

Eighty healthy adult male New-Zealand rabbits weighing between 3.1 and $3.3 \mathrm{~kg}$ were used for all experiments. Rabbits were housed in microisolator cages under specific pathogenfree conditions. All animal experiments were approved by the Institutional Animal Care and Use Committees at first center hospital. 


\section{Combined Lung Contusion and Burn Injury}

Rabbits were anesthetized with $50 \mathrm{mg} / \mathrm{kg}$ intramuscular ketamine hydrochloride. Each rabbit's right hemithorax was drawn, and a 350-g metal cylinder was dropped from a height of $150 \mathrm{~cm}$ in the supine position, as described in the study by Raghavendran et al. ${ }^{[12]}$ Trauma was standardized by applying $5.14 \mathrm{~J}$ of energy on the chest region according to the formula. The impact energy $(E)$ of the falling weight was calculated using the following equation: $E=m(0.35 \mathrm{~kg}) \times \mathrm{g}\left(9.8 \mathrm{~m} / \mathrm{s}^{2}\right) \times \mathrm{h}$ $(150 \mathrm{~cm}) .^{[13]}$

Rabbits subjected to combined injury were subjected to LC, followed by induction of 30\% TBSA full-thickness burns on the back with $90^{\circ} \mathrm{C}$ water for $9 \mathrm{~s}$.

The rabbits were randomly assigned to resuscitation groups that maintained a minimum mean arterial blood pressure of $70 \mathrm{mmHg}$ using one of the following three methods: normal saline plus polygeline injection in a ratio of $I: I(I: I G)(n=20)$, normal saline plus polygeline injection in a ratio of $\mathrm{I}: 2(\mathrm{I}: 2 \mathrm{G})$ $(n=20)$, normal saline plus polygeline injection in a ratio of $1: 3$ $(I: 3 G)(n=20)$, and control rabbits which were anesthetized, but were not injured and did not receive treatment $(n=20)$.

\section{Lung Histopathology}

The lung was excised and perfused with 10\% PBS buffered formalin. After fixation, lung tissues were embedded with paraffin and sectioned (5 um sections). The sections were stained with hematoxylin \& eosin.

\section{Electron Microscopy}

Lung tissues were post-fixed in $1 \%$ osmium tetroxide in sodium phosphate buffer and then processed and embedded in epoxy resin. Thin sections were installed on copper grids and observed on a transmission electron microscope (TEM). ${ }^{[14]}$

\section{Wet/Dry Weight Determinations}

Lung samples were separated and weighed immediately after removal to determine the wet weight. The sample was ovendried at $65^{\circ} \mathrm{C}$ for $24 \mathrm{~h}$ and re-weighed. The lung wet-to-dry weight ratio was calculated as the index of lung water content.

\section{Measurement of Myeloperoxidase (MPO) Activity}

Lungs of the rabbits from all groups were separated and homogenized. The homogenates were used to observe MPO activity. Briefly, weighed lungs were thawed and homogenized in a homogenate medium. The homogenates were then performed according to the manufacturer's instructions.

\section{Measurement of Cytokine Levels in the Serum}

TNF- $\alpha$ and IL- 8 serum levels in the rabbits were measured by enzyme-linked immunosorbent assay (ELISA), according to the manufacturer's instructions (R\&D Systems, Minneapolis, MN).

\section{Total RNA Extraction and Real-Time PCR}

Total RNA was isolated from the lung samples using a QIAGEN RNeasy Mini Kit (Dusseldorf, Germany) and treated with RNase-free DNase. RNA was reverse transcribed, and cDNA was subjected to PCR for analyzing the expression of IL-8 and TNF- $\alpha$. IL-8 sense, 5'-CAA ACC TTTCCA CCC CAA AT-3' and IL-8 anti-sense, 5'-ATT GCATCT GGC AAC CCT AC-3', amplified fragment length 572 bp; and TNF- $\alpha$ sense, 5'-TTATCT CTC AGC TCC ACG CC-3' and TNF- $\alpha$ anti-sense, 5'-TGC GCA CTG AAA GCA TGA TC-3', amplified fragment length 383 bp.

\section{RESULTS}

\section{Fluid Resuscitation Reduces Pulmonary Edema} Induced By Combined Injury

Pulmonary edema is one of the most characteristic pathologic changes in burn-induced lung injury. ${ }^{[15]}$ Meanwhile, LC leads to hypoxemia severe enough to qualify as ALI/ARDS. The lung W/D ratio was examined to determine the effect of combined injury on pulmonary edema. As shown in Figure I, the lung W/D ratio in I:3 fluid resuscitation-treated rabbits was substantially higher than that in the control group $(p<0.05)$ and lower than that in the 1:2 fluid resuscitation group. The lung W/D ratio in the $1: 2$ fluid resuscitation group was lower than that in the I:I fluid resuscitation group $(p<0.05)$, which suggests that pulmonary edema alleviated when rabbits with combined injury were treated with fluid resuscitation.

\section{Fluid Resuscitation Protects Against Histopathologic Changes Induced By Combined Injury}

As illustrated in Figure $2 \mathrm{~b}$, c, the lungs in rabbits with combined injury show apparent proinflammatory changes charac-

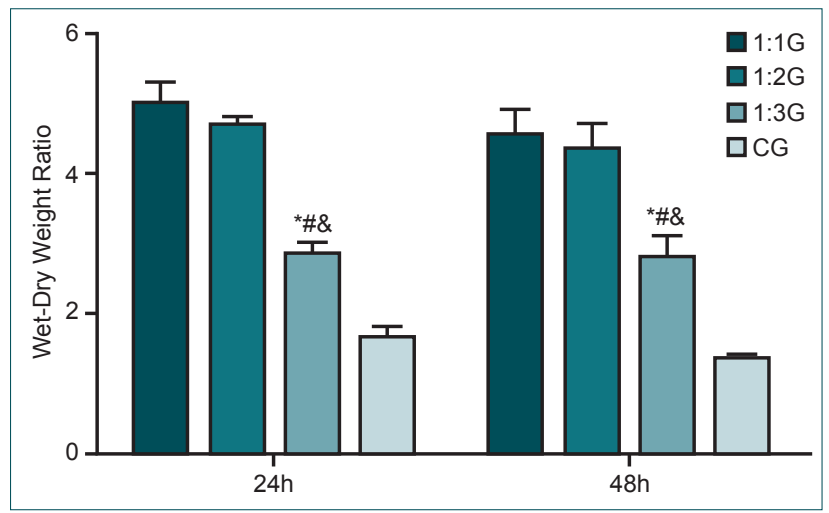

Figure 1. The wet/dry ratio of the lung for each group. The wet/ dry ratio of the lung was measured for the four groups of rabbits: control group, 1:1 fluid resuscitation group, 1:2 fluid resuscitation group, and 1:3 fluid resuscitation group. (Data are denoted as means \pm s.e.m. $n=10$ rabbits per group, ${ }^{*} p<0.05$ compared with $C G$. ${ }^{\#} p<0.05$ compared with $1: 1 \mathrm{G}$. ${ }^{\circledR} p<0.05$ compared with 1:2G. CG: Control group, 1:1G: 1:1 fluid resuscitation group, 1:2G: 1:1 fluid resuscitation group, and 1:3G: 1:1 fluid resuscitation group). 

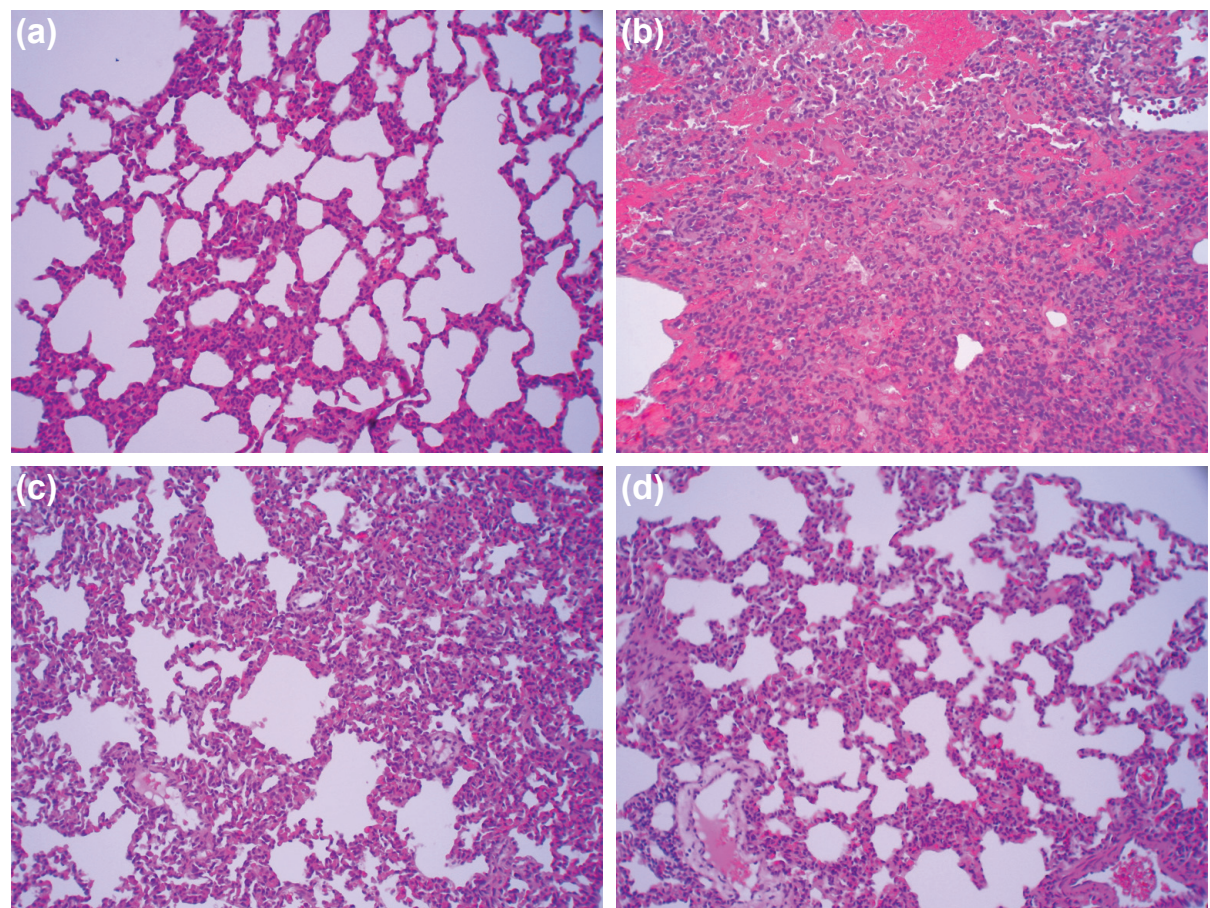

Figure 2. Histological evaluation of fluid resuscitation-treated rabbits following combined injury. These images are representative of the treatment groups at $24 \mathrm{~h}$ post injury. (a) control group, (b) 1:1 fluid resuscitation group, (c) 1:2 fluid resuscitation group, and (d) 1:3 fluid resuscitation group. $(H \& E$ staining $\times 200)(n=10$ rabbits per group, CG: control group, 1:1G: 1:1 fluid resuscitation group, 1:2G: 1:1 fluid resuscitation group, and 1:3G: 1:1 fluid resuscitation group).

terized by lung edema, alveolar hemorrhage and neutrophil infiltration, and destruction of the epithelial and endothelial cell structure. Furthermore, I:3 fluid resuscitation-treated rabbits showed significant alleviation of interstitial edema formation at $24 \mathrm{~h}$ (Fig. 2d). Conversely, no destructive changes were observed in lung tissues from the control group (Fig. 2a).
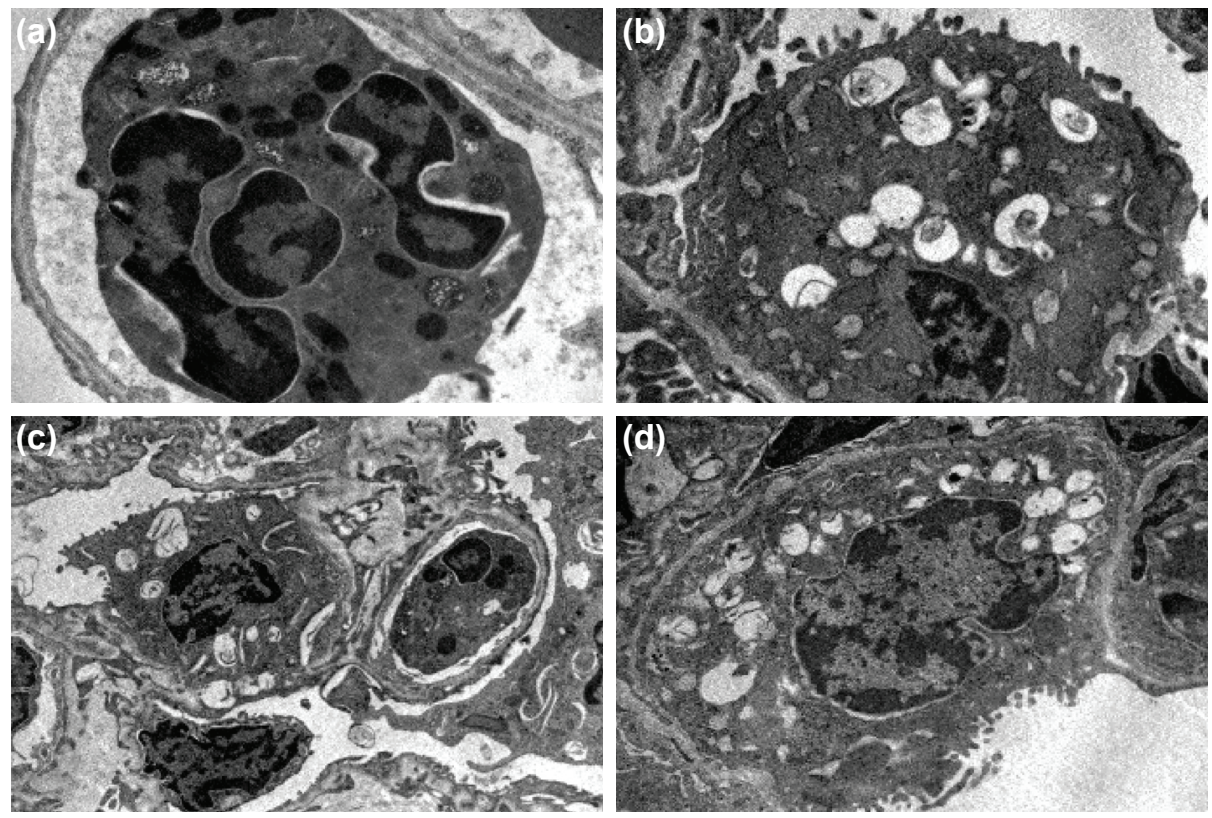

Figure 3. Electron microscopic findings of the lamellar body. (a) Electron micrograph of the lungs of the control animal that did not have an injury and did not receive any treatment. (b) TEM image of the lamellar body in the 1:1 fluid resuscitation group at $24 \mathrm{~h}$ after injury. (c) TEM image of the lamellar body in the 1:2 fluid resuscitation group at $24 \mathrm{~h}$ after injury. (d) TEM image of the lamellar body in the 1:3 fluid resuscitation group at $24 \mathrm{~h}$ after injury. ( $\mathrm{n}=10$ rabbits per group, CG: control group, 1:1G: 1:1 fluid resuscitation group, 1:2G: 1:1 fluid resuscitation group, and 1:3G: 1:1 fluid resuscitation group). 


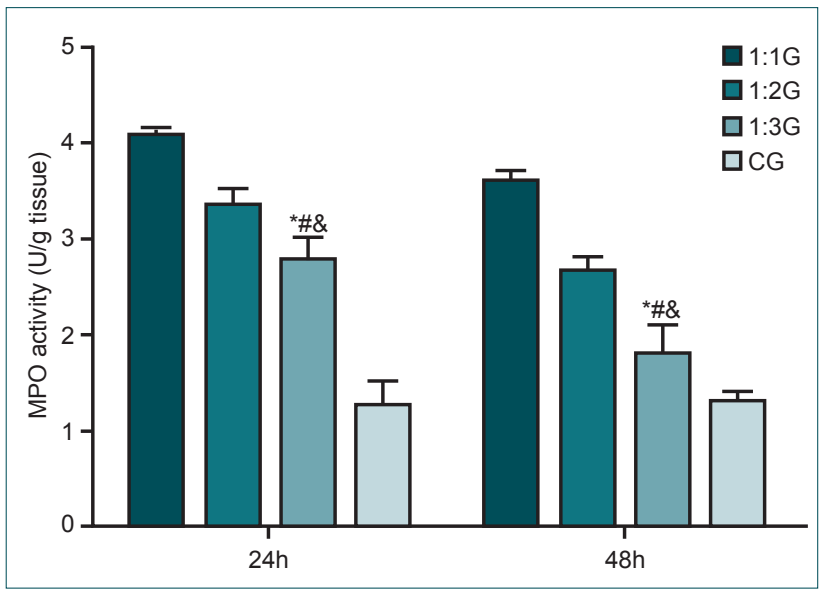

Figure 4. The MPO activity in lung homogenates. Fluid resuscitation inhibits myeloperoxidase (MPO) activity in combined injury-induced ALI. After 24 and $48 \mathrm{~h}$ interventions, rabbits were sacrificed, and their lungs were removed. The MPO activity was measured to assess the accumulation and activation of neutrophils in the lung tissues. (Data are denoted as means \pm s.e. $m, n=10$ rabbits per group, ${ }^{*} p<0.05$ compared with CG. ${ }^{*} p<0.05$ compared with 1:1G. ${ }^{\&} p<0.05$ compared with 1:2G. CG: control group, 1:1G: 1:1 fluid resuscitation group, 1:2G: 1:1 fluid resuscitation group, and 1:3G: 1:1 fluid resuscitation group).

\section{Ultrastructural Changes in Combined Injury-}

\section{Induced Lung Injury Compared With Controls}

The degree of lung injury was further observed by TEM examination of the different experimental groups. TEM exhibited that the control group had a normal lung tissue structure. Compared with other groups, we identified lamellar bodies with few cavitations in the 1:3 fluid resuscitation group (Fig. $3)$.

\section{Lung MPO Activity in Lung Injury}

Neutrophil accumulation in the lungs was determined suing MPO activity assays. ${ }^{[16]}$ MPO expression was markedly upregulated in fluid resuscitation-treated rabbits (Figure 4). This increase in MPO levels was clearly weakened in 1:3 fluid resuscitation-treated rabbits and differed obviously from that in MPO levels in I: I or I:2 fluid resuscitation treatment after injury $(p<0.05)$ (Figure 4). MPO estimates in the control group and at 24 and $72 \mathrm{~h}$ after combined injury were significantly diverse from those at all other time points in both groups $(p<0.05)$ (Figure 4).

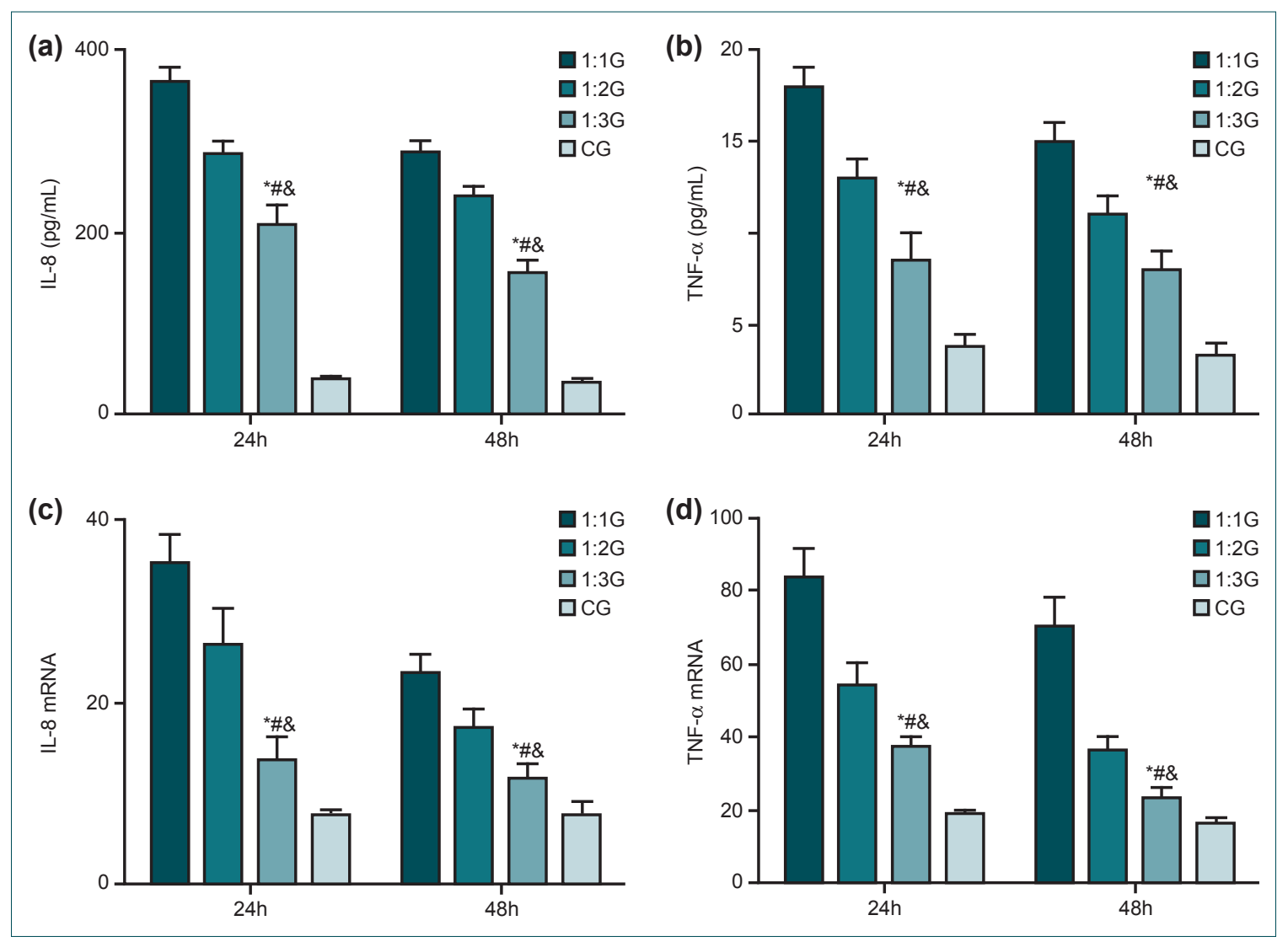

Figure 5. Effects of fluid resuscitation on inflammatory cytokine expression in combined injury-induced ALI rabbits. Serum and lung samples were obtained 24 or $48 \mathrm{~h}$ after combined injury to analyze inflammatory cytokine, including IL-8 (A), TNF$\alpha(B)$, IL-8 mRNA (C), and TNF- $\alpha$ mRNA (D), levels. (Data are denoted as means \pm s.e.m, $n=10$ rabbits per group, * $p<0.05$ compared with CG. ${ }^{*} p<0.05$ compared with 1:1G. and ${ }^{\star} p<0.05$ compared with 1:2G. CG: control group, 1:1G: 1:1 fluid resuscitation group, 1:2G: 1:1 fluid resuscitation group, and 1:3G: 1:1 fluid resuscitation group). 
Fluid Resuscitation Decreases Local and Systemic Inflammatory Mediator Levels Induced By Combined Injury

Inflammatory mediators play an important role in the pathogenesis of burn-induced ALI. ${ }^{[17]}$ TNF- $\alpha$ and IL- 8 levels in the serum were determined by ELISA. Combined injury showed elevated TNF-a and IL-8 levels in the serum in $1: I$ and $1: 2$ fluid resuscitation-treated rabbits. I:3 fluid resuscitation treatment lowered these mediator levels in the blood (Figure $5 a, b)$. In line with the measurements of the serum, I:3 fluid resuscitation-treated rabbits had substantially lower TNF- $\alpha$ mRNA and IL-8 mRNA expression levels in the lungs (Figure c, d).

\section{Statistical Analyses}

We used Student's t-test for comparing differences between groups. $\mathrm{P}<0.05$ was considered to be statistically significant. Data are expressed as mean \pm standard error of the mean (s.e.m.).

\section{DISCUSSION}

We were able to demonstrate a reduction in the severity of combined injury-induced lung injury in $1: 3$ fluid resuscitationtreated rabbits. I:3 fluid resuscitation-treated rabbits with combined injury exhibited lower pulmonary edema, alveolar hemorrhage, and neutrophil invasion after injury. The generation of proinflammatory mediators, IL-8 and TNF-a, was markedly downregulated in the I:3 fluid resuscitation group. Under conditions of combined injury, we also demonstrated lower neutrophil recruitment in the lung.

Fluid resuscitation following burn injury must support organ perfusion with the least amount of fluid necessary and the least physiological cost. ${ }^{[18]}$ Resuscitation fluids are broadly categorized into colloid and crystalloid solutions. However, it is unclear whether fluid resuscitation is closely associated with combined injury. To the best of our knowledge, this study was the first to compare strategies for fluid resuscitation after combined injury in rabbits over a midterm period of $48 \mathrm{~h}$ with histopathology and pathophysiology. Our results suggest that fluid resuscitation attenuates lung injury in rabbits after combined injury. This is supported by three findings. First, colloids are more effective than crystalloids in early resuscitation of patients in shock when administered during surgery. ${ }^{[19]}$ Our data showed that I:I fluid resuscitation-treated rabbits had obviously elevated congested alveolar capillaries, hemorrhage, and some alveolar wall thickening compared with I:3 fluid resuscitation-treated rabbits after injury (Figure 2). Type II alveolar epithelial cells proliferate to cover the injured basement membrane and differentiate into type I alveolar epithelial cells. ${ }^{[20]}$ Further, lighter ultrastructural changes were observed by TEM after $24 \mathrm{~h}$ in 1:3 fluid resuscitation-treated rabbits after combined injury. Second, a major hallmark of $A L I$ is the intrapulmonary invasion of neutrophils. ${ }^{[21]}$ The nor- mal response to pulmonary infection or injury induces the controlled recruitment of neutrophils to the lung, which are then rapidly eliminated through the induction of apoptosis and subsequent clearance by alveolar macrophages during the resolution phase of the inflammatory response. ${ }^{[22]}$ Our data are in agreement with these findings. However, we showed that an increase in the MPO activity was clearly diminished in I:3 fluid resuscitation-treated rabbits and significantly differed from that in $1: 1$ and $1: 2$ fluid resuscitation-treated rabbits at 24 or $48 \mathrm{~h}$. Third, patients with ALI/ARDS had persistent elevations in inflammatory cytokines (TNF- $\alpha$, IL-I $\beta$, and IL6) levels in the plasma, hypothalamic-pituitary-adrenal axis hormones, and similar severity of organ dysfunction scores. [23] Colloids have a possible advantage over crystalloids when used for initial hemodynamic stabilization of critically ill patients. ${ }^{[24]}$ Similarly, I:I fluid resuscitation treatment increased the release of IL-8 (Figure 5a) and TNF- $\alpha$ (Figure 5b) in the lung compared with $1: 3$ fluid resuscitation treatment. In the air space, an alveloar macrophage secretes cytokines, IL-8 and TNF- $\alpha$, which act locally to stimulate chemotaxis and activate neutrophis. ${ }^{[25]}$ Our research also shows that IL-8 and TNF- $\alpha$ levels were significantly affected at $24 \mathrm{~h}$ post injury in the $1: 3$ fluid resuscitation group compared with those in the I:I fluid resuscitation group (Figure $5 c, d$ ). Collectively, these findings suggest that fluid resuscitation significantly attenuates lung injury in rabbit. In conclusion, we were able to show that after combined injury, 1:3 fluid resuscitation-treated animals develop a less severe lung injury than different fluid resuscitation-treated animals. Further studies are needed to better understand the effects of fluid resuscitation on both neutrophil development and function in pulmonary inflammation.

\section{Acknowledgments}

We are grateful to Xueqin Zheng, Qianqian Zhang, Peng Yu, and Wanying $X i a$ for technical assistance. This study was supported by the science and technology fund of Tianjin municipal health bureau (20I2KZ020).

Conflict of interest: None declared.

\section{REFERENCES}

1. Baker TA, Romero J, Bach HH 4th, Strom JA, Gamelli RL, Majetschak M. Systemic release of cytokines and heat shock proteins in porcine models of polytrauma and hemorrhage. Crit Care Med 2012;40:876-85.

2. Busche MN, Gohritz A, Seifert S, Herold C, Ipaktchi R, Knobloch K, et al. Trauma mechanisms, patterns of injury, and outcomes in a retrospective study of 71 burns from civil gas explosions. J Trauma 2010;69:92833. [CrossRef]

3. Shuker ST. Facial skin-mucosal biodynamic blast injuries and management. J Oral Maxillofac Surg 2010;68:1818-25. [CrossRef]

4. Richard F. Oppeltz, Meenakshi Rani, Qiong Zhang, Martin G. Schwacha. Burn-induced alterations in toll-like receptor-mediated responses by bronchoalveolar lavage cells. Cytokine 2011;55:396-401. [CrossRef]

5. Skoge M, Wong E, Hamza B, Bae A, Martel J, Kataria R, et al. A Worldwide Competition to Compare the Speed and Chemotactic Accuracy of Neutrophil-Like Cells. PLoS One 2016;11:e0154491. [CrossRef] 
6. Fear VS, Poh WP, Valvis S, Waithman JC, Foley B, Wood FM, et al. Timing of excision after a non-severe burn has a significant impact on the subsequent immune response in a murine model. Burns 2016;42:815-24.

7. Kalbitz M, Karbach M, Braumueller S, Kellermann P, Gebhard F, Huber-Lang M, et al. Role of Complement C5 in Experimental Blunt Chest Trauma-Induced Septic Acute Lung Injury (ALI). PLoS One 2016;11:e0159417. [CrossRef]

8. Bakan V, Kurutaş EB, Çıralık H, Gül M, Çelik A. Endogenous erythropoietin level and effects of exogenous erythropoietin in a rat model of blunt chest trauma-induced pulmonary contusion. Ulus Travma Acil Cerrahi Derg 2016;22:322-7.

9. Peeters Y, Lebeer M, Wise R, Malbrain ML1. An overview on fluid resuscitation and resuscitation endpoints in burns: Past, present and future. Part 2 - avoiding complications by using the right endpoints with a new personalized protocolized approach. Anaesthesiol Intensive Ther 2015;47:15-26. [CrossRef]

10. Guilabert P, Usúa G, Martín N, Abarca L, Barret JP, Colomina MJ. Fluid resuscitation management in patients with burns: update. $\mathrm{Br} \mathrm{J}$ Anaesth 2016;117:284-96. [CrossRef]

11. Prunet B, Prat N, Couret D, Cordier PY, De Bourmont S, Lambert D, et al. Midterm effects of fluid resuscitation strategies in an experimental model of lung contusion and hemorrhagic shock. Shock 2014;41:159-65.

12. Raghavendran K, Davidson BA, Helinski JD, Marschke CJ, Manderscheid P, Woytash JA, et al. A rat model for isolated bilateral lung contusion from blunt chest trauma. Anesth Analg 2005;101:1482-9. [CrossRef]

13. Cohn SM, Dubose JJ. Pulmonary contusion: an update on recent advances in clinical management. World J Surg 2010;34:1959-70. [CrossRef]

14. Ryman-Rasmussen JP, Cesta MF, Brody AR, Shipley-Phillips JK, Everitt JI, Tewksbury EW, et al. Inhaled carbon nanotubes reach the subpleural tissue in mice. Nat Nanotechnol 2009;4:747-51. [CrossRef]

15. Tian KY, Liu XJ, Xu JD, Deng LJ, Wang G. Propofol inhibits burn injury-induced hyperpermeability through an apoptotic signal pathway in microvascular endothelial cells. Braz J Med Biol Res 2015;48:401-7.

16. Dienz O, Rud JG, Eaton SM, Lanthier PA, Burg E, Drew A, et al. Essential role of IL- 6 in protection against H1N1 influenza virus by promoting neutrophil survival in the lung. Mucosal Immunol 2012;5:258-66.

17. Liang X, Wang RS, Wang F, Liu S, Guo F, Sun L, et al. Sodium butyrate protects against severe burn-induced remote acute lung injury in rats. PLoS One 2013;8:e68786. [CrossRef]

18. Hodgman EI, Subramanian M, Arnoldo BD, Phelan HA, Wolf SE. Future Therapies in Burn Resuscitation. Crit Care Clin 2016;32:611-9.

19. van Haren F, Zacharowski $K$. What's new in volume therapy in the intensive care unit? Best Pract Res Clin Anaesthesiol 2014;28:275-83.

20. Ma B, Zhou PY, Ni W, Wei W, Ben DF, Lu W, et al. Inhibition of activin receptor-like kinase 5 induces matrix metallopeptidase 9 expression and aggravates lipopolysaccharide-induced pulmonary injury in mice. Eur Rev Med Pharmacol Sci 2013;17:1051-9.

21. Miyashita T, Ahmed AK, Nakanuma S, Okamoto K, Sakai S, Kinoshita J, et al. A Three-phase Approach for the Early Identification of Acute Lung Injury Induced by Severe Sepsis. In Vivo 2016;30:341-9.

22. Moorthy AN, Tan KB, Wang S, Narasaraju T, Chow VT. Effect of High-Fat Diet on the Formation of Pulmonary Neutrophil Extracellular Traps during Influenza Pneumonia in BALB/c Mice. Front Immunol 2016;7:289. [CrossRef]

23. Rizzo AN, Sammani S, Esquinca AE, Jacobson JR, Garcia JG, Letsiou $\mathrm{E}$, et al. Imatinib attenuates inflammation and vascular leak in a clinically relevant two-hit model of acute lung injury. Am J Physiol Lung Cell Mol Physiol 2015;309:1294-304. [CrossRef]

24. Perel P, Roberts I, Ker K. Colloids versus crystalloids for fluid resuscitation in critically ill patients. Cochrane Database Syst Rev 2013;28:CD000567. [CrossRef]

25. Segal LN, Clemente JC, Tsay JC, Koralov SB, Keller BC, Wu BG, et al. Enrichment of the lung microbiome with oral taxa is associated with lung inflammation of a Th17 phenotype. Nat Microbiol 2016;1:16031.

\section{DENEYSEL ÇALIŞMA - ÖZET}

\section{Tavşanlarda kombine travmanın neden olduğu akciğer yaralanmasında farklı tedavi protokollerinin değerlendirilmesi}

\section{Dr. Xiao Bing Li}

Tianjin Birinci Merkezi Hastanesi, Yanık ve Plastik Cerrahi Bölümü, Tianjin-Çin Halk Cumhuriyeti

AMAÇ: Kombine travmanın neden olduğu akciğer yaralanmasında farklı tedavi rejimlerinin etkinliğini değerlendirmeyi amaçlamaktadır. GEREÇ VE YÖNTEM: Tavşanlar ölümcül olmayan iki taraflı kapalı göğüs kontüzyonu ardından tüm vücut alanının \%30'unu tutan haşlanma yanığına maruz bırakıldı. Tavşanlar minimum ortalama arter kan basıncı 70 mmHg'nin üç yöntemle başka bir deyişle I:I, I:2 veya I:3 oranında normal salin/ poligelin enjeksiyonları ile idame ettirilen resüsitasyon gruplarından birine randomize edildi (sırasıyla, I:IG, I:2 G ve I:3 G). Travmadan sonra akciğer yaralanması ıslak/kuru (I/K) akciğer ağılığı oranı, ELISA ve gerçek zamanlı PCR analiziyle değerlendirildi.

BULGULAR: I:I veya I:2 sIVı resüsitasyon grubuna göre I:3 sIVI resüsitasyon grubunda tavşanlarda azalmış akciğer I/K oranı, alveoler kanama, MPO aktivitesi ve serumda düşük IL-8 ve TNF- $\alpha$ düzeyleri saptandı. Ayrıca I:3 sıvı resüsitasyonu uygulanan tavşanlarda kombine yaralanmadan 24 saat sonra ultrastrüktürel değişiklikler de azaldı.

TARTIŞMA: Bu çalışma kombine yaralanmaya maruz kalan akciğerde sıvı resüsitasyonunun etkisini göstermiştir. Akciğer yaralanmasının erken evresinde kombine akciğer kontüzyonu ve yanık yaralanmasından sonra I:3 sıvı resüsitasyonuyla tedavi daha efektiftir. Anahtar sözcükler: Akciğer kontüzyonu; akut akciğer yaralanması; sıvı resüsitasyonu; yanık yaralanması.

Ulus Travma Acil Cerrahi Derg 2017;23(5):362-367 doi: 10.5505/tjtes.2017.21736 